\title{
3D model for design team innovation
}

\author{
Dan $\mathrm{Li}^{*}$, Chunhong Liu*, Kang $\mathrm{Li}^{3}$ \\ Glorious Sun School of Business and Management, Donghua University, 1882 West Yan'an Road Shanghai, China
}

Corresponding Author Email: lidanabcd@163.com

\section{DOI: $10.18280 /$ rces. 050105}

Received: 6 November 2017

Accepted: 25 March 2018

\section{Keywords:}

design team innovation, 3D model, innovation path

\begin{abstract}
This paper aims to analyze the process and features of design team innovation. To this end, a 3D model was proposed for design team innovation based on design-driven innovation theory. The three dimensions include technology, market and design. After detailing the innovation process of design teams, the author analyses the innovation path of three types of enterprises: those primarily driven by design in innovation (design-oriented enterprises), those both driven by design and technology in innovation (design \& technology-oriented enterprises), and those not primarily driven by design in innovation (design-assisted enterprises). The research findings provide references for relevant design enterprises and government decision-making departments.
\end{abstract}

\section{INTRODUCTION}

This paper aims to analyze the process and features of design team innovation. To this end, a 3D model was proposed for design team innovation based on design-driven innovation theory. The three dimensions include technology, market and design. After detailing the innovation process of design teams, the author analyses the innovation path of three types of enterprises: those primarily driven by design in innovation (design-oriented enterprises), those both driven by design and technology in innovation (design \& technologyoriented enterprises), and those not primarily driven by design in innovation (design-assisted enterprises).The research findings provide references for relevant design enterprises and government decision-making departments.

\section{LITERATURE REVIEW}

Much research has been done on improving the innovation ability of design teams. The main research angles are introduced as follows:

(1) Innovation process of design teams. A design team is usually composed of a business manager, production workers, marketers, R\&D staff, assistant designers and intern designers [1]. The designers are responsible for communicating with team members, and designing new products according to consumer demand and market trend [2]. Their role has become increasingly important in the process of innovative design [3]. To promote innovation and team development, a design team should employ different types of designers with varied backgrounds based on task difficulty [4], and create a reasonable complementary structure of team members [5]. Overall, the innovation process of design teams hinges on both the integration of different resources and the understanding of market demand, social environment and cultural trend [6].

(2) Driving force of innovation in design teams. Rather than an independent stage in the classical innovation theory, design is ubiquitous in the product $\mathrm{R} \& \mathrm{D}$, application and production [7]. In 2002, the Organisation for Economic Cooperation and Development (OECD) declared that design is a critical link in enterprise innovation. Since then, the topic has attracted much attention from scholars.

To sum up, there is limited research on the path towards continuous innovation in design teams. Hence, this paper proposes a $3 \mathrm{D}$ model for design team innovation based on design-driven innovation theory. The innovation process in design team was introduced, and the main innovation paths for design teams were discussed for three types of design enterprises

\section{INNOVATION PROCESS IN DESIGN TEAMS}

The design program varies with the difficulty level of design tasks and the design team. Considering design as a multi-stage program, Cooper et al. created a model of 13 stages, including but not limited to initial scanning, preliminary assessment, financial analysis, product development, product testing, consumer testing, market testing, and so on. As shown in Figure 1, the innovation process in a design team is so complex that the team needs non-designers and experts from other departments and knowledge fields to fulfill a task.

It is impossible for a design team to achieve innovation without proper preparations. To get ready for the task, designers and non-designers must be carefully selected for the team. Then, the design goal should be set after analyzing a stream of information, and should carry one or more innovation points. Under the guidance of the goal, a design plan should be formulated to realize the innovation points through the integration of various resources. The goal setting and plan formulation are essential to the whole innovation process, as they both mobilize the enthusiasm and verify the creative ability of the design team. In the end, the design 
team innovation must be evaluated from various angles. The evaluation not only provides the team members with feedbacks on innovation, but also improves the innovative ability of the whole team.

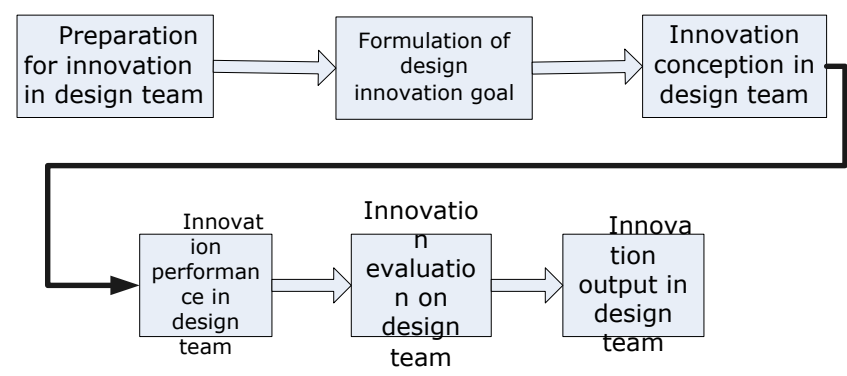

Figure 1. Innovation process in design team

\section{D MODEL FOR DESIGN TEAM INNOVATION}

The designers in the same team influence each other through the exchange of knowledge and information in design activities. To achieve innovation, the designers must consider the market demand, new technology and new invention. In addition, the aesthetic function and symbolic significance of product should also be taken into account. The major influencing factors on design innovation, namely technology, market and design, co-evolve in the innovation process into a $3 \mathrm{D}$ model for design team innovation (Figure 2).

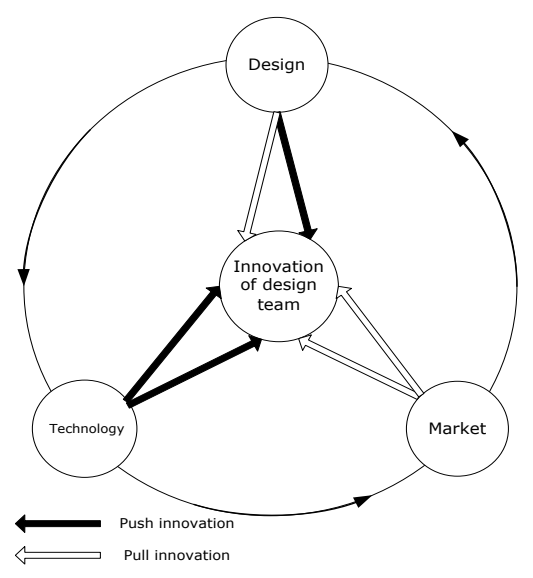

Figure 2. 3D model for design team innovation

(1) Technology-driven innovation. Technology is a necessity for innovation activities of design teams. It ensures the effectiveness in whole design process from drawings to products. In particular, technology promotes the design team innovation by elevating the innovation standard. The promotion effect is mainly reflected by the introduction of new materials and equipment, which lays the basis for the creation of innovative products. For specific design task, the application of new technology helps to perfect the user experience, and forge a scientific mindset in design. Hence, the design team should rationally utilize the most cuttingedge technology and constantly upgrade their technical knowhow, aiming to promote the innovation process and widen their design horizon.

(2) Market-driven innovation. Apart from technology, market is also an important impetus to innovation. It reveals the importance of consumer demand in innovation. To satisfy the ever-changing consumer demand, enterprises should always roll out new products reflecting the latest technology. The fulfillment of the market demand further speeds up the development of new technology, and drives the enterprise innovation. Designers have to maintain a good interaction with consumers, seeking to understand their preferences for color, material and shape. For example, sport wear designers need to be familiar with the features of different types of sports and their physical requirements for clothing.

(3) Design-driven innovation. In the traditional product development mode, the marketing department is responsible for evaluating the market demand, and the technology department is responsible for making product solutions. However, the role of the design team has been largely overlooked in the product development process. In this scenario, it is hard to ensure the competitiveness of new products. Recently, more and more enterprises are highlighting the importance of the design team. As the bridge between market and technology, the design team must emphasize on the development of product language and meanings, in addition to market demand and new technology. The focus on design enables enterprises to create new consumer demand and strength their brand power.

\section{INNOVATION PATH IN DASIGN TEAM}

From the perspective of design innovation, the enterprises mainly fall into three categories: those primarily driven by design in innovation (design-oriented enterprises), those both driven by design and technology in innovation (design \& technology-oriented enterprises), and those not primarily driven by design in innovation (design-assisted enterprises). Here, the innovation path in each of the three types of enterprises is analyzed, aiming to provide references for relevant design enterprises and government departments.

(1) Innovation path of design-oriented enterprises. Design is the primary driving force of innovation in design-oriented enterprises. In the innovation path, technology and consumer demand completely depend on the design of new product. Figure 3 shows the interaction between the factors of product language, market demand and technology in design team innovation. The solid arrows refer to the functional innovation pushed by design and the hollow arrow stands for the semantic innovation boosted by design. It can be seen that design supersedes market demand and technology in designoriented enterprises. Through the development of product languages and meanings, the emotion, symbols and culture of new product are conveyed by the product's color, texture, shape, lines, etc.

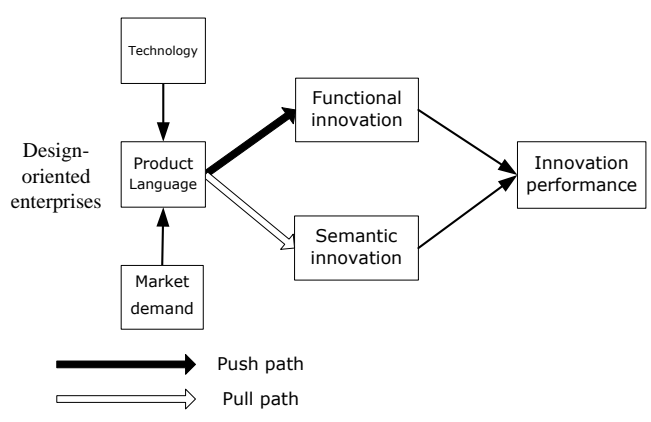

Figure 3. The innovation path of design-oriented enterprises 
(2) Innovation path of technology \& design enterprises. In this type of enterprises, the technology department and design department are often independent of each other, and technology and design are treated with equal importance. The two factors influence each other and together promote product innovation. As shown in Figure 4, a typical technology \& design enterprise has an independent R\&D centre and a design research centre. The two centres share knowledge and communicate with each other. In this way, both technology and design have a significant impact on the innovation process in this type of enterprises.

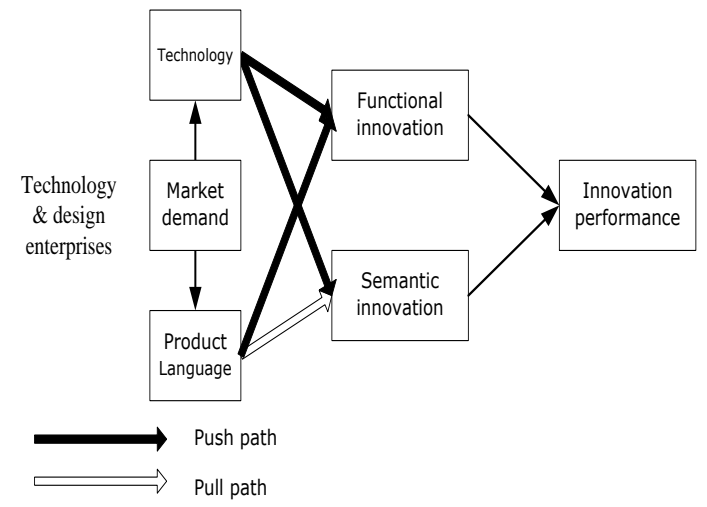

Figure 4. The innovation path of technology \& design enterprises

(3) Innovation path of design-assisted enterprises. In this type of enterprises, there is usually no independent design department or design team. Most of design tasks are outsourced to the other organizations. Technology plays a much greater role than design in design-assisted enterprises. As shown in Figure5, the product innovation mainly depends on technological innovation in this type of enterprises. Design, however, reduces the risk of technology innovation. In the long run, the innovation path of this type of enterprises will gradually evolve into that of technology \& design enterprises.

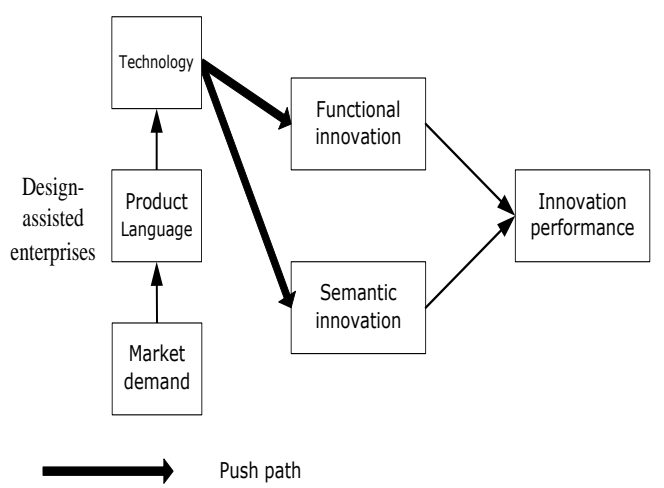

Figure 5. The innovation path of design-assisted enterprises

\section{CONCLUSIONS}

Based on design-driven innovation technology, this paper puts forward a 3D model was proposed for design team innovation. The three dimensions include technology, market and design. After detailing the innovation process of design teams, the author analyzed the innovation path of three types of enterprises: design-oriented enterprises, design \& technology-oriented enterprises, and design-assisted enterprises).Further research is expected to explore the influencing factors of design team innovation and the innovation performance of design team in different industries.

\section{ACKNOWLEDGMENT}

This research was supported by the Fundamental Research Funds for the Central Universities, China (CUSF-DH-D2016064). Humanities and social sciences project of ministry of education, China (15YJA630075). The Shanghai academy of productivity young scholars' research assistant fund, China (201608).

\section{REFERENCES}

[1] Abecassis-Moedas C, Ben Mahmoud-Jouini S, Dell'Era C. (2012). Key resources and internationalization modes of creative knowledge-intensive business services: the case of design consultancies. Creativity \& Innovation Management 21(3): 315-331. http://dx.doi.org/10.1111/j.1467-8691.2012.00646.x

[2] Chen GD, Chen Q. (2012). Research on the enterprise value with design-driven innovation: A case study on ningbo fotile. Journal of China University of Geosciences 14(7): 45-49.

[3] Chen G. (2014). An empirical research on knowledge exchange among design teams and innovation performance. Science Research Management 11(6): 1824.

[4] Chen Q, Chen GD. (2014). A study on innovation approaches and their portfolio based on 3D driver network. Studies in Science of Science 23(5): 32-36.

[5] Dell'Era C, Verganti R. (2009). Design-driven laboratories: organization and strategy of laboratories specialized in the development of radical design-driven innovations. R \& D Management 39(1): 1-20. http://dx.doi.org/10.1111/j.1467-9310.2008.00541.x

[6] Luchs M, Swan KS. (2011). Perspective: The emergence of product design as a field of marketing inquiry. Journal of Product Innovation Management 28(3): 327-345. http://dx.doi.org/10.2139/ssrn.1645313.

[7] Zhang K, Qing YU, Dong SF. (2012). Analysis of brand design features based on product experience. Packaging Engineering 33(24): 54-56. 